\section{METALLIC ARTIFACTS OF ARJAN-MAYEMIR PERIOD FROM THE ALTAI TERRITORY: X-RAY FLUORESCENCE ANALYSIS, CULTURAL AND CHRONOLOGICAL ATTRIBUTION*}

Alexey A. Tishkin

Altai State University, Barnaul, Russia

\begin{abstract}
At present, the Russian archaeologists' task is a more intensive study of the materials that have been accumulated earlier. Modern methods of natural science are used to achieve this objective. These methods are intended to provide the necessary volume of objective information to verify the earlier conclusions, concepts and assumptions, as well as to reach a new level of research activity. The determining of the chemical composition of metal finds is particularly important in this process. The data acquired from the field where the work has not been carried out at all or it has been accomplished fragmentally are of remarkable value. The author of the article scheduled and sequentially executed the program of study of Arjan-mayemir archaeological finds (end of IX - 2-3 quarters of the VI century BC.) that have been studied with the help of X-ray fluorescence spectrometer ALPHA SERIES ${ }^{\mathrm{TM}}$ (Alpha-2000, USA), which is available at the Department of Archaeology, Ethnography and Museology of Altai State University. Published results are based on research, which was based on archaeological finds stored in the Museum of Archaeology and Ethnography of the Altai State University (Barnaul). The most representative is the collection obtained during the excavation of the monument Elekmonar-II. Moreover the ancient objects of archaeological sites such as Bijkye, Boytygem-II and Tytkesken-VI were also involved. All of them show different stages of development of Biyken archaeological culture. An incomplete set of elements of horse equipment is used as a comparative material from the museum which reflects another tradition within the designated chronological period. Artifacts from location Gilevsky Bridge also refer to Mayemir (Mayemer) culture.

Key words: Altai, Arjan-mayemir time, X-ray fluorescence analysis, spectrometer, museum, tools, items of arms, jewelry, items of clothing, horse gear.
\end{abstract}

DOI: $10.14258 /$ tpai(2017)1(17).-09

\title{
Introduction
}

At present, the Russian archaeologists' task is the intensive study of a significant amount of material that has been already accumulated. The modern methods of natural science are used for this purpose. They are aimed at the supplying of the necessary volume of objective information in order to verify the earlier conclusions, concepts and assumptions, as well as achieving a new level of research activity. In this process, the determining of the chemical composition of metal finds is especially important. The data acquired in the spheres where the work was not carried out at all or has been implemented fragmentally are of particular value. The author of the article has planned and has been consistently performing the program of study of metal items from Arjan-mayemir time (end of IX - 2-3 quarters of the VI century BC.). These ancient finds were obtained during the excavation of archaeological sites in the mountains and foothills of the Altai territory.

* Исследование выполнено при финансовой поддержке гранта Правительства РФ (Постановление №220), полученного ФГБОУ ВО «Алтайский государственный университет», договор №14.Z50.31.0010, проект «Древнейшее заселение Сибири: формирование и динамика культур на территории Северной Азии», а также в рамках реализации государственного задания Алтайского государственного университета (проект №33.867.2017/ПЧ, «Реконструкции технологических приемов и методов производств древних обществ Северной Азии»). 


\section{Materials and methods}

Scientific research results published in the paper are based on the study of archaeological finds preserved in the Museum of Archaeology and Ethnography of Altai the Altai State University (Barnaul, Russia). The most representative collection was obtained during the excavation of the memorial Elekmonar-II by N. Stepanova. These materials have been published and received interpretation [Stepanova, 1996; Kiriushin, Tishkin, 1997, p. 40, 43-62, 65, 68-76, 78-80, etc.; Shulga, 2008, p. 170-171; Tishkin, 2011, p. 279-283, Fig. 2.-2, 30, 40, 42-45; Fig. 3.-5-7, 9, 12-16, 49; Fig. 4; Fig. 6.-2-5; etc.]. In addition, there was a research of other ancient objects from such archaeological sites as Bijkye [Tishkin, 1996], Boytygem-II [Abdulganeev, 1994] and Tytkesken-VI [Kiriushin, Tishkin, 1997, p. 38-48, Fig. 9-12; Kiriushin, Tishkin, Matrenin, 2011, p. 97-104]. All of them exemplify different stages of the development of Biyken archaeological culture of the Altai territory [Tishkin, 2007a, p. 94-97; 2007b, p. 146-158; 2011, p. 277-286; etc.].

Metal objects were studied in this museum with a portable X-ray fluorescence spectrometer ALPHA SERIES ${ }^{\mathrm{TM}}$ Alpha-2000 (USA), which is available at the Department of Archaeology, Ethnography and museology of the Altai State University. The description of the device, of the method and of the implemented approach is presented in recently published monographs [Tishkin, Seregin, 2011, p. 61-65]. About use of a X-ray fluorescent method in archaeological researches many scientific works both foreign are written [Kearns, MartinónTorres, Rehren, 2010; Steven Shackley, 2012; Shugar, 2013; Orfanou, Rehren, 2014; etc.], and the Russian experts.

An incomplete set of elements of horse equipment from the location Gilevsky Bridge was used as a comparative material [Tishkin, 1998, p. 79-81, 87-88, Fig. 1-2], which reflects another tradition within this chronological period. These products refer to Mayemir (Mayemer) culture [Tishkin, 2003, p. 165-166] and are also stored in the Museum of Archaeology and Ethnography of Altai the Altai State University. It should be mentioned that X-ray fluorescence analysis of the samples from these findings was previously made by S.V. Khavrin [2008, p. 176]. It was carried out in the Laboratory of scientific and technical expertise of the State Hermitage. Our results presented in this article were obtained directly from the study of these ancient items, and the spectrometer testing was carried out in different parts of the objects. In the mentioned paper by S.V. Khavrin [2008, p. 177] the preliminary determination of the chemical composition of three findings from the memorial Elekmonar-II (buckle, hook, knife) is presented. This article offers complete conclusions concerning metal objects of this archaeological complex.

The research conducted by now offers the opportunity to relate the studied objects with developed cultural and chronological scheme of the ancient history of the Altai territory [Tishkin, 2007a, p. 236]. Archaeological items of Biyken culture were mainly found in the excavated mounds and are represented by different categories (tools, weapons, horse gear, jewelry, etc.). Their fixed characteristics are presented according to their functional usage. The main focus will be placed on the X-ray fluorescence analysis, which was performed for the first time for most of these artifacts.

\section{Results and discussion}

Tools. First there was a comprehensive study of the bronze knife (Fig. 1.-1; Fig. 2.-1) found in the memorial Bijkye [Tishkin, 1996, p. 22]. The item is fairly massive, with an arcuate butt which length is $18,5 \mathrm{~cm}$. The handle is separated from the blade with the blade's heel; 
the handle is widening to the top and has a vertical protrusion on one side serving almost at right angle to the plane of the blade. The item was cast in the two-side mold, as evidenced by traces of casting seam on the handle, rim and butt. The blade was sharpened. The blade has a recess or groove on one side, its width is up to $0,65 \mathrm{~cm}$. Bevel butt has segment editing. The knife has a curved form.
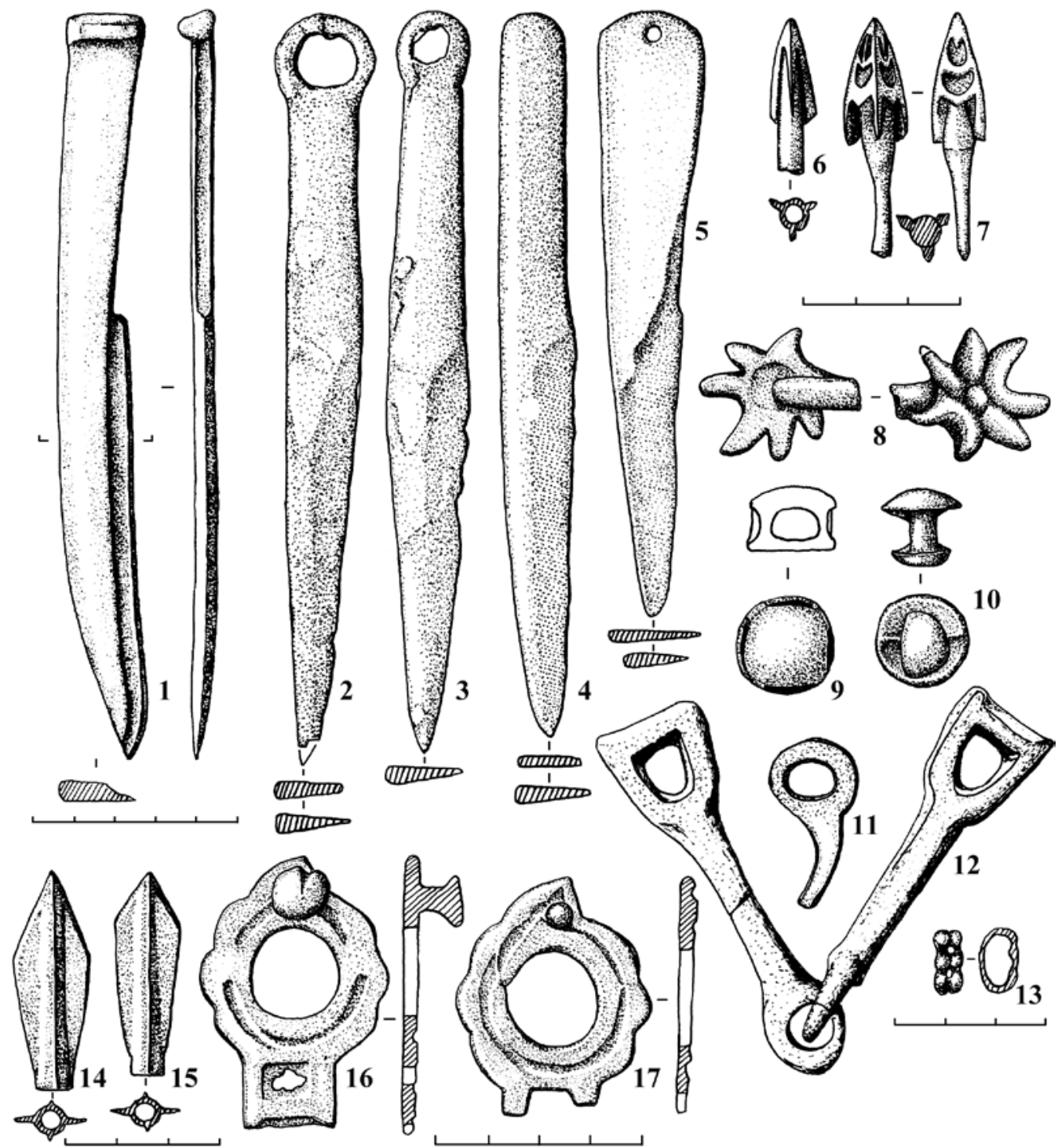

Fig. 1. Metallic artifacts of Arjan-mayemir period from monuments of Altay: 1 - Biyke; 2-13, 16-17 - Elekmonar-II; 14-15 - Tytkesken-VI

First X-ray fluorescence spectrometer results were obtained during the study of piecemeal structure in the center of the blade covered with a thick patina. They were as follows: $\mathrm{Cu}$ (copper) - 88,94\%; Sn (tin) - 6,09\%; As (arsenic) - 3,34\%; Sb (antimony) - 0,74\%; $\mathrm{Ni}$ (nickel) - 0,51\%; Pb (lead) - 0,22\%; Bi (bismuth) - 0,16\%. Then it was tested the place 
where formerly the scientist from the Institute of Archaeology (The Russian Academy of Science) took samples for spectral analysis: $\mathrm{Cu}-89,9 \%$; $\mathrm{Sn}-6,75 \%$; $\mathrm{As}-2,24 \%$; $\mathrm{Ni}-0,52 \%$; $\mathrm{Fe}$ (iron) $-0,33 \% ; \mathrm{Pb}-0,26 \%$. The next stage of the research involved the study of a small portion of the butt, which was neatly cleaned from the oxides by mechanical means*. The figures from real metal surface were obtained: $\mathrm{Cu}-90,28 \%$; $\mathrm{Sn}-6,52 \%$; As $-1,51 \%$; $\mathrm{Sb}-0,69 \% ; \mathrm{Ni}-0,61 \% ; \mathrm{Pb}-0,3 \% ; \mathrm{Fe}-0,09 \%$. For such object as a knife, it is important to check the composition of the alloy of its working part. Therefore tip of the blade purified from the patina was tested: $\mathrm{Cu}-90,97 \%$; $\mathrm{Sn}-5,7 \%$; $\mathrm{As}-2,58 \%$; $\mathrm{Ni}-0,52 \% ; \mathrm{Pb}-0,23 \%$. The complex of available data suggests that the object is made of bronze. The basis of the alloy is copper with natural (ore) impurities (arsenic, antimony, nickel, etc.). Fixed amount of tin is an artificial additive, used to enhance the quality of the tool.

Among the findings, similar to Biyken knife, there is also a similar bronze object from Bolsherechensk culture BE-XIV burial [Gryaznov, 1956, p. 71, tab. XXI.-19]. There are also a number of common features with the same subject from the nearest memorial Ust-Kuyum [Marsadolov, 1981, p. 21, Fig. 4]. Knives like biyken knife are common for the ancient cultures, located to the east and south-east of the Mountain Altai. Time of their appearance is determined by the end of the Late Bronze Age [Chlenova, 1967, p. 166-180, Tab. 37; 1972, Tab. 72, 86]. The western border of fixing such findings is the territory of modern Kazakhstan [Steppe zone ..., 1992, p. 142, 145, Tab. 56]. The knives discovered there are dated within the VIII - the beginning of the VI BC. In order to establish the chronology of existence of biyken knife it is necessary to consider not only the existing range of analogies. The archaic design should also be considered as well as the fact that this product was found in the mound №2, which is one of the earliest burials in Bijkye complex. Therefore, the period of its manufacture and use was defined within the framework of VIII-VII centuries BC, which is consistent with the lifetime of Late Karasukh and Karasukh-Tagar forms of bronze knives [Kiriushin, Tishkin, 1997, p. 77]. Later refined dating (2nd half VIII - 1st half of VII century $\mathrm{BC}$ ) is reflected in reference to the stages of the development of Biyken archaeological culture [Tishkin, 2007b, Fig. 3].

Next it was studied a series of metal knives (Fig. 1.-2-5; Fig. 2.-2-5) which comes from the specified monument Elekmonar-II [Stepanova, 1996, p. 56, 64, 67, Fig. 6.-1-4] and differs from previous findings from Bijkye. These metal objects were investigated as follows. First the surface covered with patina was tested, then one of the segments was mechanically cleaned of oxides and finally the alloy itself was studied. The results of X-ray fluorescence analysis of the objects are presented in this order, and they are as follows.

Plate blade with a relatively large ringed pommel and a length of $14,6 \mathrm{~cm}$ (Fig. 1.-2; Fig. 2.-3):

1) $\mathrm{Cu}-59,03 \% ; \mathrm{Sn}-37,62 \% ; \mathrm{Pb}-1,43 \% ; \mathrm{As}-1,01 \% ; \mathrm{Fe}-0,75 \%$; $\mathrm{Bi}-0,15 \%$;

2) $\mathrm{Cu}-57,17 \%$; $\mathrm{Sn}-41 \% ; \mathrm{Pb}-0,96 \%$; $\mathrm{As}-0,51 \% ; \mathrm{Fe}-0,36 \%$.

Plate blade with a small ringed pommel with $14,6 \mathrm{~cm}$ in length (Fig. 1.-3; Fig. 2.-2):

1) $\mathrm{Cu}-59,02 \% ; \mathrm{Sn}-37,49 \% ; \mathrm{Pb}-1,64 \%$; $\mathrm{As}-1,25 \% ; \mathrm{Fe}-0,53 \%$; $\mathrm{Ni}-0,07 \%$;

2) $\mathrm{Cu}-59,11 \%$; $\mathrm{Sn}-36,68 \%$; $\mathrm{Pb}-1,49 \%$; As $-1,12 \%$; Fe - 1,05\%; Ti (titanium) $-0,46 \%$; $\mathrm{Ni}-0,09 \%$.

${ }^{*}$ This procedure is not damaging for the museum exhibits as opposed to drilling, sawing, breaking and other similar option sampling. Moreover, the maximum removal of oxides including mechanical way is a mandatory step in implementing restoration of ancient metal products. But before this the object will be restored, it must be sure to thoroughly explore. 


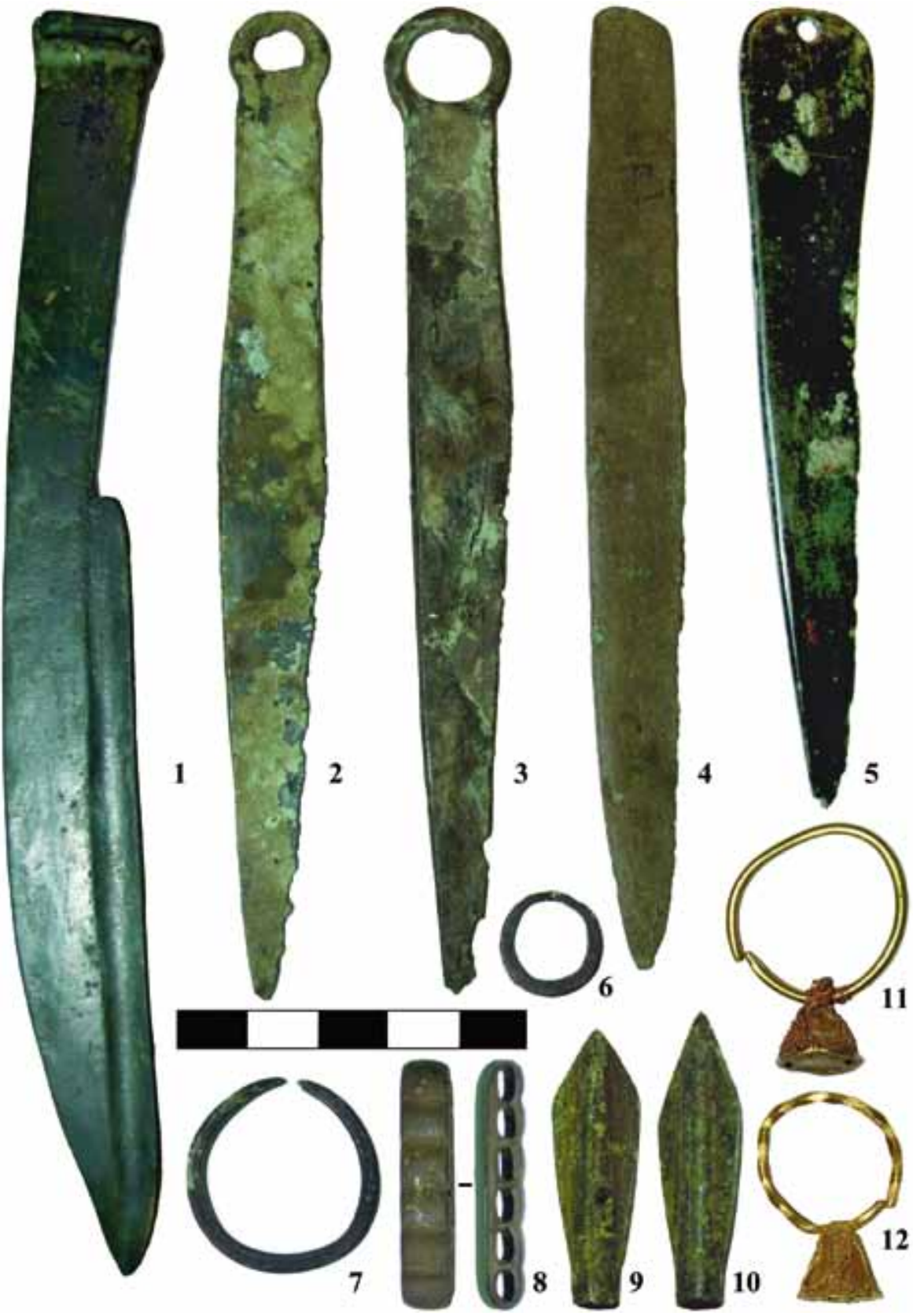

Fig. 2. Artifacts from the monuments of Biyken archaeological culture

Plate knife without issuing tops, length $14,3 \mathrm{~cm}$ (Fig. 1.-4; Fig. 2.-4):

1) $\mathrm{Cu}-73,33 \%$; $\mathrm{Sn}-22,07 \%$; $\mathrm{Fe}-3,21 \%$; $\mathrm{As}-0,75 \%$; $\mathrm{Ti}-0,54 \% ; \mathrm{Pb}-0,1 \%$;

2) $\mathrm{Cu}-85,59 \%$; $\mathrm{Sn}-13,44 \%$; $\mathrm{As}-0,53 \% ; \mathrm{Fe}-0,27 \% ; \mathrm{Pb}-0,17 \%$.

Plate blade (12 cm long) with an expanding handle on the end of which there is a small aperture (Fig. 1.-5; Fig. 2.-5): 
1) $\mathrm{Cu}-56,57 \% ; \mathrm{Sn}-41,04 \% ; \mathrm{Fe}-1,27 \%$; $\mathrm{Ti}-0,35 \%$; As $-0,33 \% ; \mathrm{Pb}-0,3 \%$; $\mathrm{Ni}-0,14 \%$;

2) $\mathrm{Cu}-51,72 \% ; \mathrm{Sn}-46,71 \% ; \mathrm{Pb}-0,8 \% ; \mathrm{As}-0,34 \% ; \mathrm{Fe}-0,29 \% ; \mathrm{Ni}-0,14 \%$.

All mentioned objects from the memorial Elekmonar-II are made of bronze. As part of their alloys stands high tin content (from 13,44 to 46,71\%), which is a characteristic feature for metal products Altai "Early Scythian" time [Khavrin, 2008, p. 173-178]. The circle of analogies to these objects has been already determined [Stepanova, 1996, p. 67]. It should be added that one of the knives (Fig. 1.-5; Fig. 2.-5) finds a match among the finds discovered during the excavation of Arzhan-2 [Čugunov, Parzinger, Nagler, 2010, Taf. 94.-2], which dates back to the VII century BC. However, a set of excavated objects fixed on the memorial Elekmonar-II allows to pre-determine the date within the 1st half of the VII century BC [Kiriushin, Tishkin, 1997, p. 43-62, 65, 68-76, 78-80, etc.; Tishkin, 2007b, Fig. 2].

Items of weapons. Of these, at our disposal were only arrowheads. They come from two sites: Elekmonar-II (Fig. 1.-6-7; Fig. 3.-15-16) and Tytkesken-VI (Fig. 1.-14-15; Fig. 2.-9-10). The following results of x-ray analysis were gained (all subjects were studied twice, in different places; the first number reflects the surface element test with removed oxides, and the second - with the oxides).

Elekmonar-II, mound №10. Trilobate arrowhead with a protruding sleeve length of 3,1 cm (Fig. 1.-6; Fig. 3.-16). Judging by the performance of the chemical composition, the item is likely to be characterized as copper. The presence of arsenic and the lead in the first case can be regarded as the ore impurities. The origin of additionally detected oxide elements may be different.

1) Acute: $\mathrm{Cu}-97,24 \% ; \mathrm{As}-2,5 \% ; \mathrm{Pb}-0,26 \%$;

2) Sleeve: $\mathrm{Cu}-95,82 \% ; \mathrm{As}-2,74 \% ; \mathrm{Sn}-0,42 \% ; \mathrm{Pb}-0,36 \% ; \mathrm{Bi}-0,33 \% ; \mathrm{Fe}-0,33 \%$.

Elekmonar-II, mound №4. Stemmed arrowhead length of $4,8 \mathrm{~cm}$ with a triangular three-blade relief-pen (Fig. 1.-7; Fig. 3.-15). It can be labeled as bronze. the device fixed copper-tin-lead alloy:

1) Acute: $\mathrm{Cu}-70,99 \% ; \mathrm{Pb}-14,69 \% ; \mathrm{Sn}-14,33 \%$;

2) The stalk: $\mathrm{Cu}-66,64 \%$; $\mathrm{Sn}-17,61 \% ; \mathrm{Pb}-12,88 \%$; As - 1,14\%; $\mathrm{Fe}-0,62 \%$; $\mathrm{Zn}$ (zinc) $-0,58 \%$; $\mathrm{Ti}-0,53 \%$.

Dating and analogies for arrowheads from Elekmonar-II have been reviewed in publications [Stepanova, 1996, p. 66-67; Kiriushin, Tishkin, 1997, p. 83; et al.]. Most often the area of their occurrence was broad, and the indicated time range was from the beginning of VII till the beginning of V age BC. Such items are still rare in the Altai territory. Chronology can be adjusted due to the dating of other finds from the memorial.

The following arrowheads come from the mound №56 of Tykesken-VI complex. They are of the same type: bronze socketed, two-bladed, rhomb shape, without thorns. The sleeve is well expressed, a little in favor of the blade, slightly expanded at the base, and is rounded inside at the center. The tip is tetrahedral. On both sides of the items the ribs are clearly marked, which were to enhance their ability to penetrate and destroy [Kiriushin, Tishkin, 1997, p. 81-82].

An arrowhead has a feather shape close to a symmetrical rhomb and has a length of $4,3 \mathrm{~cm}$ (Fig. 1.-14; Fig. 2.-10). Judging by the results of X-ray fluorescence analysis, the basis of the alloy was copper ore with impurities (arsenic, lead). Tin was used as the dopant. High lead content can be considered as an additional artificial impurity. 

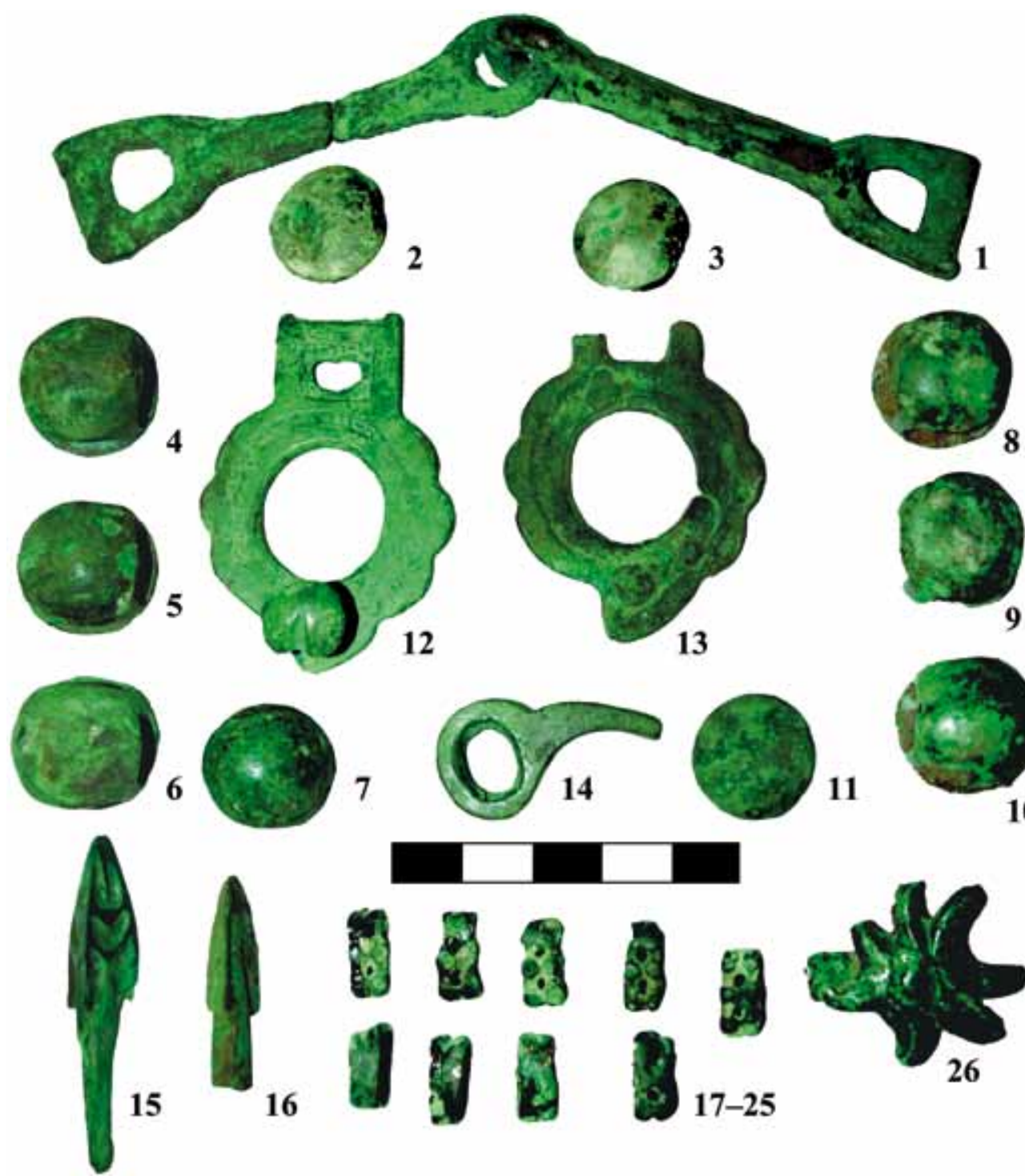

11

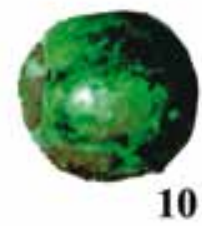

10

Fig. 3. Complex of finds from the monument Elekmonar-II

1) $\mathrm{Cu}-87,1 \%$; $\mathrm{Sn}-11,32 \% ; \mathrm{Pb}-1,17 \% ; \mathrm{As}-0,41 \%$;

2) $\mathrm{Cu}-87,86 \%$; $\mathrm{Sn}-10,67 \%$; $\mathrm{Pb}-0,98 \%$; As $-0,33 \%$; $\mathrm{Fe}-0,16 \%$.

Arrowhead (Fig. 1.-15; Fig. 2.-9), $4 \mathrm{~cm}$ length differs from the previous one, not only with asymmetrically feather-rhombic shape, but with the presence of the hole on the sleeve. Element parameters fixed with spectrometer are similar to the previous data. The difference lies only in the absence of arsenic.

1) $\mathrm{Cu}-96,85 \% ; \mathrm{Sn}-2,37 \% ; \mathrm{Pb}-0,78 \%$;

2) $\mathrm{Cu}-95,44 \% ; \mathrm{Sn}-3,25 \% ; \mathrm{Pb}-1,07 \% ; \mathrm{Fe}-0,24 \%$.

Two-bladed bronze socketed arrowheads found in the burial mound №56 memorial Tytkesken-VI (Fig. 2.-9-10) are likely to appear in the Altai territory in the 2nd half of the 
VIII BC, but they became the most "popular" in VII-VI centuries BC [Kiriushin, Tishkin, 1997, p. 81-82; Tishkin, 2007b, Fig. 3 and 6]. It should be mentioned that items of this type were not found in a well dated "royal" mound Arzhan-2 [Chugunov, 2011, p. 296-324]. At the same time, similar arrowheads are found in the mound Arzhan-1 [Gryaznov, 1980, Fig. 11.-12], the date of construction of which is determined by of the end of IX - beginning of the VIII BC [Eurasia in the Scythian epoch ..., 2005, p. 88-89]. Currently, the need for typological analysis of the Arjan-mayemir arrowheads found in South Siberia and adjacent regions on the basis of well-dated systems is highlighted.

Ornamentals and items of clothing. To the objects that are associated with a person's clothing, apparently relates a peculiar strap fragment found on the memorial Elekmonar-II (Fig. 1.-8; Fig. 3.-26). "Badge with radiating spikes" is from the mound №4 [Stepanova, 1996, p. 64, 67, Fig. 6.-12]. Such objects are not typical for Biyken Altai culture. Intact badges were found for example in Mongolia [Volkov, 1967, Fig. 20.-17; Tengeriyn ild..., 2011, p. 172] and in the Trans-Baikal [Stupnikov, 1974, p. 107-109; Grishin, 1975, p. 137-138, Fig. 49.-2]. There are similar findings in other regions as well. In our opinion, they were not only ornamentals, but they were also functionally significant items of nomads' clothing of Arjan-mayemir time in Central Asia and adjacent territories. As for the pictures, there can be different interpretations because the pictures are stylized. However, judging by the numerous findings from Mongolia, the starting point is the image of the head of a deer [Tengeriyn ild ..., 2011, p. 166-169].

There are three sets of the X-ray fluorescence analysis of the mentioned fragment:

1) the middle part of the "star" surface (the surface in the burial was subjected to diverse factors): $\mathrm{Cu}-90,23 \%$; $\mathrm{Sn}-7,86 \%$; $\mathrm{As}-1,46 \%$; $\mathrm{Pb}-0,19 \% ; \mathrm{Fe}-0,14 \%$; $\mathrm{Ti}-0,12 \%$;

2) the section from the inner side of one of the spikes cleaned from oxides: $\mathrm{Cu}-93,05 \%$; $\mathrm{Sn}-6,14 \%$; As - 0,53\%; $\mathrm{Pb}-0,28 \%$;

3) scrapped trims: $\mathrm{Cu}-93,12 \% ; \mathrm{Sn}-6,03 \%$; $\mathrm{As}-0,55 \%$; $\mathrm{Pb}-0,22 \% ; \mathrm{Fe}-0,08 \%$.

The presented results are quite close to each other and demonstrate alloy, which is based on a set of copper in combination with ore impurities (arsenic, lead, iron, and titanium). Tin was used as an artificial additive but not in such a large extent that could radically affect functionality, color and other characteristics of the product. What was the reason for scrapping of the product is not easy to find out. The thing could be shared on purpose, although not quite quality casting should be also considered.

Metal links for bracelet can also be identified as jewelry (Fig. 1.-13; Fig. 3.-17-25). They are also found on the memorial Elekmonar-II and represent a set of "nine links" [Stepanova, 1996, p. 66, Fig. 7.-IV]. Similar links were found in the mound Arzhan-2, but there they were used to decorate the strap by which the bronze mirror was hung from the belt [Čugunov, Parzinger, Nagler, 2010, Taf. 66.-6b; Taf. 80.-1].

$\mathrm{X}$-ray fluorescence spectrometer tested all of these objects from Elekmonar-II:

1) $\mathrm{Cu}-48,26 \% ; \mathrm{Sn}-51,58 \% ; \mathrm{Pb}-0,16 \%$;

2) $\mathrm{Cu}-53,66 \% ; \mathrm{Sn}-46,34 \%$;

3) $\mathrm{Cu}-53,02 \%$; $\mathrm{Sn}-46,98 \%$;

4) $\mathrm{Cu}-62,52 \% ; \mathrm{Sn}-36,13 \% ; \mathrm{Fe}-1,35 \%$;

5) $\mathrm{Cu}-54,18 \%$; $\mathrm{Sn}-45,82 \%$;

6) $\mathrm{Cu}-51,35 \%$; $\mathrm{Sn}-48,64 \%$;

7) $\mathrm{Cu}-53,78 \%$; $\mathrm{Sn}-44,88 \%$; $\mathrm{Fe}-1,34 \%$; 
8) $\mathrm{Cu}-60,02 \%$; $\mathrm{Sn}-39,39 \% ; \mathrm{Fe}-0,59 \%$;

9) $\mathrm{Cu}-49,78 \%$; $\mathrm{Sn}-50,22 \%$.

The results indicate that a special kind of recipe was used for the manufacture of jewelry. The presented figures demonstrate consistently high percentage of tin in the alloy. This fact suggests the attempt of giving the jewelry the "noble" color and proper look.

The following studied objects are earrings (Fig. 2.-11-12). They were found during excavations of the mound №19 on the memorial Boytygem-II [Abdulganeev, 1994, p. 3738], and are now stored in the Museum of Archaeology and Ethnography of the Altai State University. There are plenty of analogous jewelry available [Vasjutin, Sadovoi, 1999, p. 36, Fig. 1.-B; Semenov, 1999, p. 166-168; Čugunov, Parzinger, Nagler, 2010, Taf. 33.-3; 57.-2b; 58.-1; 72.-1; 91.-1-2; 97.-1; 99.-3, 5; 102.-1; 106.-5-6; 110.-1-5; et al.). The determined time of their existence is VII-V centuries BC [Kiriushin, Tishkin, 1997, p. 90]. Therefore, there should be immediately considered that the chronology of the burial mounds of Biyken culture Boytygem-II, proposed by M.T. Abdulganeev [1994, p. 38], is clearly older than it is in reality and it is not consistent with the definition of the chronology of all the data obtained in the study of the memorial.

The most appropriate date of excavated objects there may be a 2 nd half of VII - beginning of VI age BC, based not only on the analysis of the elements of horse equipment but also taking into account the review of the terms of analogies [Kiriushin, Tishkin, 1997, p. 112; Marsadolov, 1998, p. 9, 13; Tishkin, 1999, p. 187], as well as attracting calibrated radiocarbon dates of Arzhan-2 mound [Eurasia in the Scythian epoch ..., 2005, p. 85-87], where similar earrings were fixed. These circumstances allow to consider these items along with other findings very important chronological indicators. This publication will display for the first time the results of their X-ray fluorescence analysis. But first, it makes sense to briefly introduce the technology of manufacturing gold objects.

One earring weighing 4,25 grams. (inv. №313) is referred to as "broken" (Fig. 2.-11). The other, weighing 3,06 grams. (inv. №314), defined as "the whole" (Fig. 2.-12) consists of two parts ("ring" and "cone") made separately and then joined together by soldering. Bearing part ("ring") has raised surface and a rhombic cross-sectional shape. Despite the furnished face, thickenings are also present. In addition, there are also traces of reeling, stretching and clamps, which are obtained, possibly during the faceting of the wire and while turning it into a ring. Different ways of wire manufacturing which served as a workpiece of numerous gold and other metal products, have been known since ancient times [Minzhulin, 1990, p. 236; Eniosova, Saracheva, 1997, p. 299-300]. In order to obtain a uniform wire thickness and smooth surface, it was rolled between the stone, metal, wooden and other devices, and then it was polished. It is difficult to determine by visual inspection and without experiments how the earring from Boytygem-II was made faceted. Perhaps it was forged in a circle or alternated by bilateral clamping. One way or another, but the effect of the techniques used is striking: originally built by numerous facets shine at different degrees of light and "come alive" in a move involuntarily drawing attention. Considered design "ring" has analogies in products from Arzhan-2 [Čugunov, Parzinger, Nagler, 2010, Taf. 106.-5-6; 110.-1, 3], although there are differences in details.

The ring of the "whole" earring is not closed and has a diameter of about $2 \mathrm{~cm}$. The thickness at the ends of the bent wire is a little more than $0,1 \mathrm{~cm}$. As for the size of the hollow "cone" which is firmly soldered to the "ring" with the use of grain, its height and diameter 
are identical $-1,15 \mathrm{~cm}$. The fact of such a relation is marked in some other similar products [Kadyrbaev, 1974, p. 45]. You can set the sequence of manufacturing of the second part of earrings - jewelry "cone". First a specially-marked stripe was cut of a sheet of gold foil, to which the necessary conical shape was given. Manufacturing technology of thin plates of gold is well known since ancient times [Minzhulin, 1990, p. 235-236, Fig. 3]. Then, a circle base of the "cone" was cut of the foil but most likely it was attached at end of the process of manufacture. The smooth surface of the foil rolled into a cone was first ornamented with a "decorated" wire, and then from the bottom up - with grain.

Manufacturing of the so-called decorated wire which had several types and was used to create filigree products, has already attracted the attention of researchers, which is reflected in the literature (see.: [Eniosova, Saracheva, 1997, p. 300]). In ancient times, there was no universal technology of grain and filigree. Each artist chose his own way. In the considered case the jewel is decorated with granulation as well as with evenly spaced and soldered to the "cone" surface of five identical elements made of "decorated" wire which were gently curled of separate stripes of thin foil beforehand.

The whole golden Boytygem-II earring's ornamental motifs are found in the Altai and adjacent territories on items of Arjan-mayemir time and a little later [Kiriushin, Tishkin, 1997, Fig. 66.-4; Zavituhina, 1966, Fig. 3.-3; Borodayev, Mamadakov, 1985, Fig. 6.-9; et al.). It is defined in different ways: as a "comma", drops, a leaf, or a stylized bird's head. This element as a kind of original fine module is also presented on objects from Arzhan-2 [Čugunov, Parzinger, Nagler, 2010, Taf. 1, 2, etc.].

Another important component under consideration is the earrings' grains. This is one of the oldest methods of artistic decoration of metal, which was carried out manually. Its essence is as follows: the product is decorated with small metal balls, stacked and attached to the surface and to each other in the form of any patterns or solid coating that creates a spectacular texture, gives the item extraordinary elegance and unique play of light and shade [Minzhulin, 1990, p. 231]. Although every ancient artist had his little secrets in the manufacture of grain, nevertheless, this process is considered to be simple. It has been repeatedly described in the publications and confirmed by the experiment [Tishkin, 1999, p. 189]. The main difficulty in the making of products with grains is not the manufacture of its parts, and the sequence of processing methods, the order of mounting and soldering method [Minzhulin, 1997, p. 236]. The same problems arise in the study of ancient jewelry. For a more specific answer to the question of how and by which means grains on ancient jewelry were attached, it is necessary to conduct microstructural analysis and other special laboratory tests. By visual observation it can only be assumed that the grains and "decorated" wire were attached to the surface of the cone and connected to each other by means of high-grade gold solder. Traces of which are clearly visible on the spot of the fallen away ornament [Tishkin, 1999, Fig. 1.-2]. The "decorated" wire was slightly deformed in some places while soldering. Grains on the earring from Boytygem-II are almost identical and they were placed tightly, but in some spots the balls have fallen away or were not attached at all.

The base of "cone" was also soldered, and for firm fixing the edge of the foil was curled, covering a number of grains in some places. This part of the "cone" has eight holes [Tishkin, 1999, Fig. 1], which are arranged in pairs and perpendicular respectively to each other. Most likely, these holes with a diameter of about $1 \mathrm{~mm}$ were made already after the plate was soldered and finally attached. They were pinned with an awl at an angle of $30^{\circ}$ 
in facing each other couples, so that they could thread the yarn or string to form a complex composite decoration of beads, as stipulated in the study of Arzhan-2 [Čugunov, Parzinger, Nagler, 2010, Taf. 110.-5]. As such, the decoration was ready for use. Apparently, Boytygem earrings were decorated in this way as evidenced by numerous found beads [Abdulganeev, 1994, p. 37].

The second ("broken") earring is an obvious imitation of the mentioned above product. It is different in size, weight, color, technique, details of general appearance, as well as the location and number of holes arranged in the bottom of the "cone" for additional hangers (they are 10 there in a circle - 10 pcs., five pairs). "The Ring" is of a bit larger diameter, it was made of a smooth $1 \mathrm{~mm}$ thick wire of a light yellow color, to which a hollow cone of thin foil (its height $-1,4 \mathrm{~cm}$ diameter at the base $-1,2-1,3 \mathrm{~cm}$ ) it soldered, it was decorated with irregular beadings with rough imitation of the discussed above ornament. Due to the fact that the artist was not as skilled, which is well noticeable from the defective soldering, the artist also had to make a through hole in transgressed "cone" so that the decoration could be used in a slightly distorted form. This part of the product is different in color from the "ring" and has a reddish color, which most likely appeared during assembly and soldering of grain. Some metal balls changed the initial shape, and some just disappeared. In the "cone" after its decoration even more holes of diameter less than $1 \mathrm{~mm}$ were made, one - is fixed at the top, and two - at the bottom. Lower holes almost coincide with the holes made in the ground and may be somehow connected. Similar and not very high-quality goods are found in Arzhan-2 mound [Čugunov, Parzinger, Nagler, 2010, Taf. 110.-2, 4].

The first results of the study of the geochemical composition of the products presented in Boytygem-II were obtained in the Laboratory of Mineralogy and Geochemistry of Tomsk State University in the semi-quantitative spectral analysis of samples taken (performer - E. Agapova). The following figures are given in percent by weight, i.e. demonstrates the percentage of the chemical composition by weight (mass percent ratio - one way of expressing the percentage concentrations of the substances). For a broken product, they are as follows: $\mathrm{Au}$ (gold) - > 0,1; $\mathrm{Si}$ (silicon) - 0,03; $\mathrm{Cu}-0,01 ; \mathrm{Fe}-0,01 ; \mathrm{Ag}$ (silver) - 0,005; $\mathrm{Mg}$ (magnesium) - 0,003; Al (aluminum) - 0,003; $\mathrm{Na}$ (sodium) - 0,003; $\mathrm{Sn}-0,001$; Ca (calcium) $-0,001 ; \mathrm{Bi}-0,0003$. For the whole earring results are: $\mathrm{Au}->0,1 ; \mathrm{Cu}-0,001$; $\mathrm{Ag}-0,002$; Mn (manganese) - 0,001; Ca - 0,001 [Tishkin, 1999, p. 188]. In the same sequence, both items were tested with an X-ray fluorescence spectrometer.

First smooth wire which was used to make a "ring" for the broken earring was tested in different places. The results were almost identical:

1) $\mathrm{Au}-74,77 \% ; \mathrm{Ag}-22,38 \% ; \mathrm{Cu}-2,85 \%$;

2) $\mathrm{Au}-74,42 \% ; \mathrm{Ag}-23,03 \% ; \mathrm{Cu}-2,55 \%$;

3) $\mathrm{Au}-74,96 \% ; \mathrm{Ag}-22,41 \% ; \mathrm{Cu}-2,63 \%$.

In addition the place on the "ring" where the cone was soldered was also tested. Metal there is a little different in color. The elements are as follows $\mathrm{Au}-67,66 \%$; $\mathrm{Ag}-25,97 \%$; $\mathrm{Cu}-6,1 \% ; \mathrm{Fe}-0,27 \%$ ) the results display the high content of copper.

Next the pendant was studied. First, its lower part with holes was double-tested: $\mathrm{Au}-$ 66,99\%; $\mathrm{Ag}-28,85 \% ; \mathrm{Cu}-2,32 \%$; $\mathrm{Sn}-1,05 \% ; \mathrm{Fe}-0,71 \%$; $\mathrm{Ni}-0,08 \%$; $\mathrm{Au}-67,22 \%$; $\mathrm{Ag}-28,99 \% ; \mathrm{Cu}-2,47 \% ; \mathrm{Sn}-1,01 \% ; \mathrm{Fe}-0,31 \%$. Then, the result concerning grains was obtained: $\mathrm{Au}-61,63 \%$; $\mathrm{Ag}-32,59 \%$; $\mathrm{Cu}-2,38 \%$; $\mathrm{Sn}-1,28 \%$; $\mathrm{Fe}-2,12 \%$. Finally, the edge of the cone without beading was further investigated: $\mathrm{Au}-62,93 \%$; $\mathrm{Ag}-33,03 \%$; 
$\mathrm{Cu}-2,13 \% ; \mathrm{Sn}-0,97 \% ; \mathrm{Fe}-0,94 \%$. The most unusual in these results is the presence of tin. This fact can provide a fresh look on the options for attaching gold beads. The use of tin for soldering metal parts in the "early Scythian" time was found in the study of mirror from the monument Maly Gonbinsky Cordon-1 (Tishkin, Seregin, 2011, p. 68, tab. V). Although it is possible that "cone" of the gold earring could receive oxides from bronze objects. This problem requires additional research. In any case, such element as tin cannot be a natural impurity in gold.

The whole earring was subject to comprehensive X-ray fluorescence spectrometer testing. First faceted surface of the ring was tested in different places. The results are practically identical.

1) $\mathrm{Au}-88,43 \% ; \mathrm{Ag}-10,47 \% ; \mathrm{Cu}-1,1 \%$;

2) $\mathrm{Au}-88,85 \% ; \mathrm{Ag}-10,18 \%$; $\mathrm{Cu}-0,97 \%$;

3) $\mathrm{Au}-88,52 \% ; \mathrm{Ag}-10,46 \% ; \mathrm{Cu}-1,02 \%$.

Then the bottom of the pendant was studied. The obtained parameters are similar to the previous ones: $\mathrm{Au}-88,5 \% ; \mathrm{Ag}-10,14 \% ; \mathrm{Cu}-1,04 \% ; \mathrm{Fe}-0,32 \%$. Grain probe marked the same characteristic as the previous product, i.e. the presence of small amounts of tin and iron: $\mathrm{Au}-83,56 \% ; \mathrm{Ag}-11,98 \%$; $\mathrm{Cu}-2,52 \% ; \mathrm{Fe}-1,29 \%$; $\mathrm{Sn}-0,65 \%$. A similar pattern was observed when testing the cone and wire: $\mathrm{Au}-84,41 \% ; \mathrm{Ag}-11,89 \% ; \mathrm{Cu}-2,28 \%$; $\mathrm{Fe}-0,79 \%$; $\mathrm{Sn}-0,63 \%$.

It should be noted that the intact earring is made delicately and skillfully. It can undoubtedly play a leading role among the masterpieces of the jeweler's art of Scythian-Sak time found in the Altai territory. Judging by the results of X-ray fluorescence analysis, highquality gold was used for the manufacturing of this jewelry. This is also marked by a bright yellow color of the precious metal of which the earring was made.

Comparing the two finds from Boytygem-II it is easy to assert that they were made by the artists with different skills. The closest analogy was found during excavations of burial mounds №8 and 14 at Bystrianskaya village, on the right bank of the Katun river (in the northern foothills of the Altai) [Zavituhina, 1966, p. 62-64]. The importance of studying of Boytygem jewelry should be viewed as an opportunity for further, more detailed and comparative analysis of the existing number of similar products within the previously planned program of research [Tishkin, 1999, p. 185-186]. Similar artistic images were fixed on the "deer" rocks (vertical anthropomorphous stones covered with the carvings of stylized deer) of the Central Asian region [Kubarev, 1979, p. 47, tab. XVI; Savinov, 1994, p. 104-109; Volkov, 2002, Tab. 33.-1; 34.-1; 103.-2; et al], which allows to date these anthropomorphic stele, that is considered to be the source for the reconstruction of the outfit of Arjan-mayemir period [Tishkin, Usova, 2011].

Another group of objects of this category was found in the memorial Tytkesken-VI. Two earrings and belt clip (Fig. 2.-6-8) come from the excavated burial mound №97. They were found while clearing and dismantling the mound. The studied object did not contain the burial. Under its southwestern slope a small ash pan was found, where another bronze clip was discovered. The materials were published and attributed to Biyken archaeological culture [Kiriushin, Tishkin, Matrenin, 2011, Fig. 4]. Those findings were specifically studied with the help of X-ray fluorescence spectrometer. First a small "earring" in the form of a closed ring was studied (Fig. 2.-6). For this purpose, from the surface of one side of the article the oxides were mechanically removed. The testing of this area indicated that the product is made of copper: $\mathrm{Cu}-99,17 \%$; $\mathrm{As}-0,67 \% ; \mathrm{Pb}-0,16 \%$. 
The second earring has larger dimensions (Fig. 2.-7). It was also covered with a thick layer of oxides, which required a careful removal. The prepared site was studied in two different points. The obtained figures indicate that the basis of the alloy was copper with ore impurities:

1) $\mathrm{Cu}-98,52 \% ; \mathrm{As}-1,16 \% ; \mathrm{Fe}-0,22 \% ; \mathrm{Pb}-0,1 \%$;

2) $\mathrm{Cu}-98,76 \% ; \mathrm{As}-1,12 \% ; \mathrm{Fe}-0,12 \%$.

The belt clip visually distinguished by the presence of unusual patina color (Fig. 2.-8). Therefore, the facial surface of the product was studied first. The results are the following: $\mathrm{Cu}-85,31 \% ; \mathrm{Sn}-12,32 \% ; \mathrm{Fe}-1,23 \% ; \mathrm{Sb}-0,61 \% ; \mathrm{Pb}-0,53 \%$. For further research the reverse side was mechanically cleaned from oxides, and was twice tested with spectrometer in different places:

1) $\mathrm{Cu}-86,56 \% ; \mathrm{Sn}-12,26 \%$; $\mathrm{Sb}-0,68 \% ; \mathrm{Pb}-0,3 \% ; \mathrm{Bi}-0,11 \% ; \mathrm{Fe}-0,09 \%$;

2) $\mathrm{Cu}-86,76 \% ; \mathrm{Sn}-12,38 \% ; \mathrm{Sb}-0,5 \% ; \mathrm{Pb}-0,28 \% ; \mathrm{Fe}-0,08 \%$.

These results display the copper-tin alloy with ore impurities, among which antimony content stands high, which probably defines the color feature of the find's surface.

The bronze cages are important for the dating of the burial mound №97 Tytkesken-VI. These elements of waist accessories bear a resemblance with the products of the aforementioned burial mound №14 from Bystrianskaya village [Zavituhina, 1966, Fig. 3.-9-11]. Similar items were found in other "Early Scythian" burials of Altai and Kazakhstan [Shul'ga, 2008, fig. 82]. The time existence of those things is determined by the 2 nd half VII $-2-3-$ th quarter of VI century BC.

Horse equipment. The elements of horse equipment are displayed by the group of finds from the mound №1 from Elekmonar-II memorial (Fig. 1.-9-12, 16-17; Fig. 3.-1-10). They were obtained during the archaeological expedition of the Altai State University and the results were published [Stepanova, 1996, Fig. 3]. All products were studied with X-ray fluorescence spectrometer. First the items of small size were tested in different places (Fig. 1.-12; Fig. 3.-1). They are two-part, connected-segmented, with smooth and rounded in cross-section rods units; have bell-like stirrup outline. One link is broken. The study of the surface coated with oxides, showed the following set of indicators: $\mathrm{Cu}-65,67 \% ; \mathrm{Pb}-28,78 \%$; $\mathrm{Sn}-2,31 \% ; \mathrm{Zn}-1,48 \%$; $\mathrm{Ti}-1,41 \% ; \mathrm{Fe}-0,35 \%$. To specify the necessary information and the comparative analysis the mechanical cleaning of edge fragments was carried out: $\mathrm{Cu}-77,62 \% ; \mathrm{Pb}-20,2 \% ; \mathrm{Sn}-1,98 \% ; \mathrm{Fe}-0,2 \%$. These figures are most likely to demonstrate copper-lead-tin alloy.

This was followed by a series of data obtained on a link:

1) inner ring: $\mathrm{Cu}-58,81 \% ; \mathrm{Pb}-38,24 \%$; $\mathrm{Sn}-1,74 \% ; \mathrm{Fe}-1,21 \%$;

2) the middle of the link: $\mathrm{Cu}-64,96 \% ; \mathrm{Pb}-32,25 \% ; \mathrm{Sn}-1,95 \% ; \mathrm{Fe}-0,84 \%$;

3 ) the edge of the stirrup without oxides: $\mathrm{Cu}-75,49 \%$; $\mathrm{Pb}-22,03 \%$; $\mathrm{Sn}-2,1 \%$; $\mathrm{Fe}-0,38 \%$.

All recorded data indicate that, for the manufacture of two similar units of stirrup a similar copper-lead-tin alloy was used.

Another object to study was the buckle with a pin (Fig. 1.-16; Fig. 3.-12). To determine the chemical composition first the portion of the outer side of the product (the "nose"), from which the oxides were mechanically removed was investigated. The spectrometer checked the following set of alloy elements: $\mathrm{Cu}-64,95 \% ; \mathrm{Pb}-26,52 \% ; \mathrm{Sn}-8,53 \%$. Then the intact surface of the product was tested in two places: 
1) peg: $\mathrm{Cu}-25,52 \% ; \mathrm{Pb}-54,42 \%$; $\mathrm{Sn}-19,11 \%$; $\mathrm{Bi}-0,43 \% ; \mathrm{Fe}-0,41 \% ; \mathrm{Zn}-0,11 \%$;

2) on the frame: $\mathrm{Cu}-41,93 \% ; \mathrm{Pb}-37,68 \% ; \mathrm{Sn}-15,67 \% ; \mathrm{Zn}-2,03 \%$; $\mathrm{Ti}-1,96 \%$; $\mathrm{Fe}-0,73 \%$.

The difference of the checked parameters from the previous result can be explained with the presence of abundant oxides. In these cases, a high content of lead and tin is observed, which is caused by the active processes of oxidation of the products and does not reflect the real balance of components of a copper-lead-tin alloy.

Together with the previous product the seat buckle fastening block was used (Fig. 1.17; Fig. 3.-13). The item was covered with a layer of adhesive on one side. So it was fixed on a stand in the exhibition. Testing was carried out twice in the areas with the removal of oxides:

1) tip: $\mathrm{Cu}-53,81 \% ; \mathrm{Pb}-38,5 \% ; \mathrm{Sn}-7,69 \%$;

2) scrap frame: $\mathrm{Cu}-52,68 \% ; \mathrm{Pb}-39,24 \% ; \mathrm{Sn}-8,08 \%$.

The results demonstrate the copper-lead-tin alloy, similar in composition to the formulation of the previous product. Perhaps they were made together, as they were intended for the pair use.

Testing of the alluvial belt ornaments in the form of "hook" (Fig. 1.-11; Fig. 3.-14) revealed the following results:

$\mathrm{Cu}-48,11 \% ; \mathrm{Pb}-40,71 \% ; \mathrm{Sn}-10,92 \% ; \mathrm{Fe}-0,26 \%$.

In this set there are six links for connection and distribution of horse ammunition belts (Fig. 1.-9; Fig. 3.-4-6, 8-10). All these subjects were individually studied with X-ray fluorescence spectrometer. The similar results indicating the copper-lead-tin alloys were obtained:

1) №669: $\mathrm{Cu}-48,45 \% ; \mathrm{Pb}-45,9 \% ; \mathrm{Sn}-5,11 \% ; \mathrm{Fe}-0,54 \%$;

2) №673: $\mathrm{Cu}-40,47 \% ; \mathrm{Pb}-55,01 \% ; \mathrm{Sn}-4,14 \% ; \mathrm{Fe}-0,38 \%$;

3) №665: $\mathrm{Cu}-42,85 \% ; \mathrm{Pb}-48,01 \% ; \mathrm{Sn}-8,89 \% ; \mathrm{Fe}-0,25 \%$;

4) №668: $\mathrm{Cu}-48,59 \% ; \mathrm{Pb}-43,47 \% ; \mathrm{Sn}-6,95 \% ; \mathrm{Fe}-0,99 \%$;

5) №670: $\mathrm{Cu}-42,9 \% ; \mathrm{Pb}-49,48 \% ; \mathrm{Sn}-7,43 \% ; \mathrm{Fe}-0,19 \%$;

6) №667: $\mathrm{Cu}-51,21 \% ; \mathrm{Pb}-41,05 \%$; $\mathrm{Sn}-7,49 \% ; \mathrm{Fe}-0,25 \%$.

Likewise, all the known and available mushroom-like fasteners were studied (Fig. 1.-10; Fig. 3.-2-3, 7, 11). But there are differences in the content of the main components in the recorded natural impurities compared to the previous results:

1) $\mathrm{Cu}-76,27 \% ; \mathrm{Pb}-20,05 \% ; \mathrm{Sn}-3,52 \% ; \mathrm{Zn}-0,16 \%$;

2) $\mathrm{Cu}-67,43 \% ; \mathrm{Pb}-27,47 \% ; \mathrm{Sn}-4,21 \% ; \mathrm{Fe}-0,74 \% ; \mathrm{Zn}-0,15 \%$;

3) $\mathrm{Cu}-50,89 \% ; \mathrm{Pb}-39,52 \%$; $\mathrm{Sn}-8,9 \%$; As $-0,55 \%$; Fe $-0,14 \%$;

4) $\mathrm{Cu}-43,92 \% ; \mathrm{Pb}-48,12 \% ; \mathrm{Sn}-7,96 \%$ (№664).

The studied set of horse equipment objects from Elekmonar-II was initially dated by VII-VI centuries BC [Stepanova, 1996, p. 66-67]. Then its chronology was identified by the 2 nd half of VIII - 1st half of VII century BC. on the basis of archaic use of three hole psaly made of horns in combination with common type of bronze bridle [Kiriushin, Tishkin, 1997, p. 65, 68-71; Tishkin, 2007b, Fig. 2]. Currently, P.I. Shul'ga [2008, p. 66] without giving any reason determines the existence of these psaly as «near the end of VII - beginning of VI centuries BC» and considers it the most later. However, according to the abundant material from Arzhan-2 [Čugunov, Parzinger, Nagler, 2010, Taf. 126-147], as well as to other monuments, including the Altai memorials [Kiriushin, Tishkin, 1997, p. 63-76], from the middle of VII century BC and later, this type of horn psaly was not 
used then. Therefore, it is more logical to date the findings from the mound №1 of Elekmonar-II with the 1 st half of VII century BC.

Next metal set of horse equipment comes from the location Gilevsky Bridge, which was discovered on the shore of the reservoir formed by the waters of the river Aley, not far from the north-western foothills of the Altai [Tishkin, 1998, p. 79]. Before presenting the results of the next study of these products, it is necessary to dwell on the following point. The monograph of P.I. Shul'ga [2008, p. 143, 157-158, 173, 179] for some reason refers Gilevsky Bridge to the burial ground Gilevo-X although the things found there are clearly not from the burial, which is proved by the safety of products, with no oxide damages. Such a conclusion seems to be associated with inattentive reading of Shulga of my article [Tishkin, 1998], where the circumstances of the finds are given in detail as well as the results of a special research. It should also be noted that in the monograph by P.I. Shulga [2008] there is a significant amount of distortion, errors and misunderstandings, so it is necessary to refer to the original sources while working with it.

Now let's turn to the characteristics and results of separate elements' X-ray fluorescence analysis of horse equipment from Gilevsky Bridge location, which refers to the monuments of Mayemir (Mayemer) culture [Tishkin, 2003, p. 165; 2011, Fig. 12].

The excavated horse bridles (Fig. 4.-1; Fig. 6.-3) - are made of two parts, and they are connected with rings. The links are relatively smooth and round in cross-section with stirrup outer ends with holes of pawn-like outline. The total length of the considered horse bridles in the unfolded state is $27,4 \mathrm{~cm}$. One whole-molded unit was slightly bent. In this way it has a length of $9 \mathrm{~cm}$ (inner ring $-1,7 \mathrm{~cm}$, the external stirrup design $-2,8 \mathrm{~cm}$, the core portion $-4,5 \mathrm{~cm}$ ). The second link - is straight with tips in different planes (perpendicular to each other). The maximum length of this part is $-9,5 \mathrm{~cm}$ (including the inner ring $-2,3 \mathrm{~cm}$, the external bridle design $-2,8 \mathrm{~cm}$, the core portion $-4,4 \mathrm{~cm}$ ). The thickness of the rods of both links is about $0,8 \mathrm{~cm}$ in the center.

These parameters indicate that the parts are virtually identical, taking into account the bending of one of the links. The exception is the inner rings, one is smaller and another is larger. This fact indirectly points to the way of connecting of these two parts. The first whole unit was cast in the two-way split mold. This is evidenced by a well fixed casting seam. The considered part of horse bridle looks better than the second, which differs with numerous defects obtained during its manufacture and connection to the previous link. The porous surface and cuts indicate that the used mold had cracks and other defects. Moreover, the traces of mechanical action on the rod are clearly visible.

First the area in the central part of the first link was tested with the help of X-ray fluorescence spectrometer. The following indicators were fixed: $\mathrm{Cu}-98,1 \%$; $\mathrm{Sn}-1,94 \%$; $\mathrm{Pb}-0,05 \%$. Then there was studied the same product in the place where S.V. Khavrin took a very small sample from the casting seam. The following elemental set was obtained: $\mathrm{Cu}-97,49 \% ; \mathrm{Sn}-2,22 \% ; \mathrm{Pb}-0,16 \% ; \mathrm{Fe}-0,13 \%$. For additional result minor oxides at the end of the stirrup were removed: $\mathrm{Cu}-97,77 \% ; \mathrm{Sn}-2,17 \% ; \mathrm{Pb}-0,06 \%$. These data display the copper-tin alloy with minor impurities.

Another link with the defects was also studied in four places. This approach was driven by an attempt to find out if the production of the second part was simultaneous with the first, as well as by the need to compare with previous analytical information. The first data were obtained when testing the junction of the outer end of the rod and were as follows: 
$\mathrm{Cu}-96,18 \% ; \mathrm{Sn}-3,66 \% ; \mathrm{Pb}-0,16 \%$. Then the influx of casting seam at the location where samples were taken by S.V. Khavrin was studied: $\mathrm{Cu}-96,1 \%$; $\mathrm{Sn}-3,79 \%$; $\mathrm{Pb}-0,11 \%$. The following results were fixed on the surface of the inner ring without the removal of the oxides and then after their removal:

1) $\mathrm{Cu}-95,94 \% ; \mathrm{Sn}-3,98 \% ; \mathrm{Pb}-0,08 \%$;

2) $\mathrm{Cu}-95,99 \% ; \mathrm{Sn}-3,93 \% ; \mathrm{Pb}-0,08 \%$.
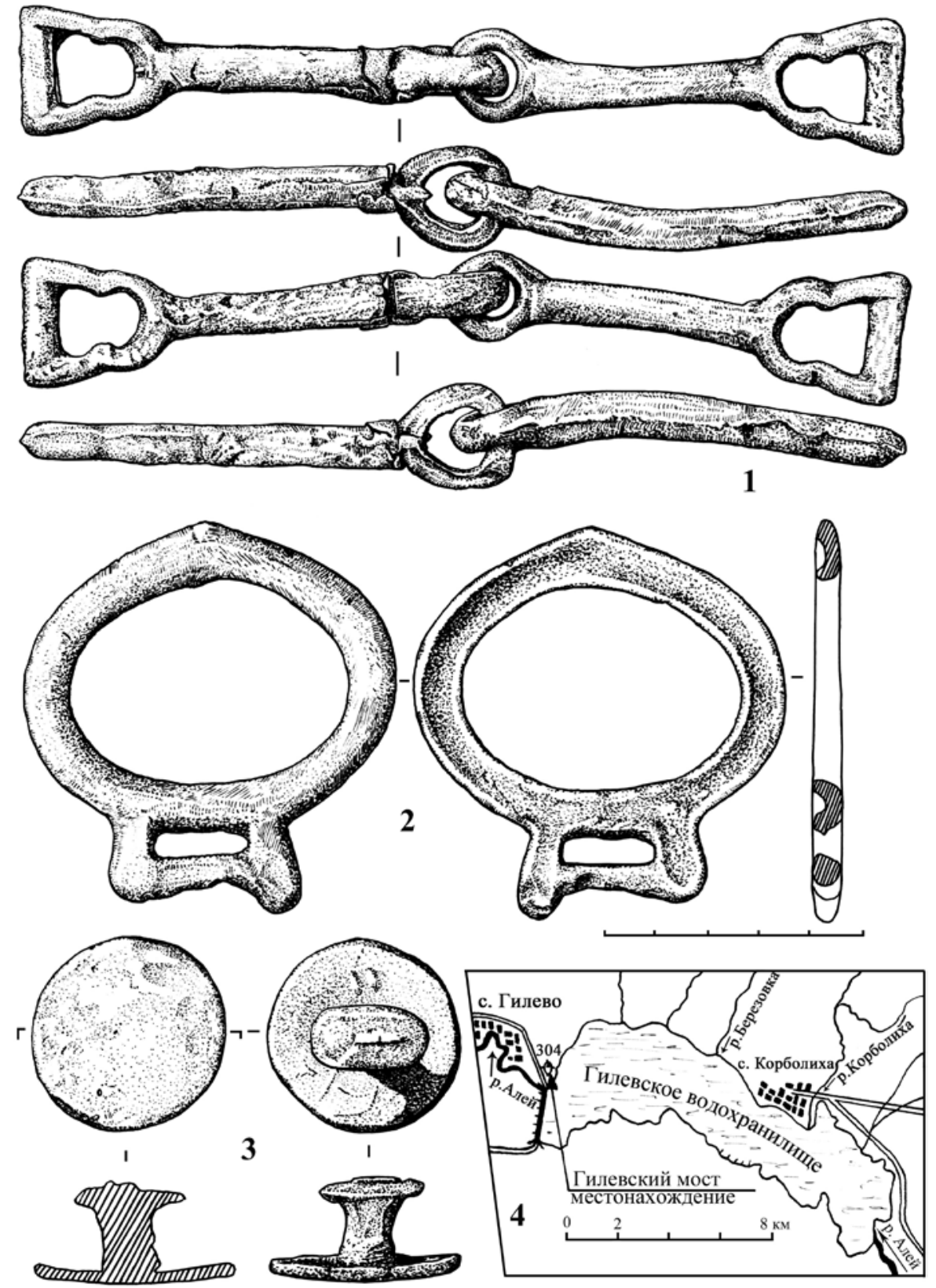

Fig. 4. Site Gilevsky Bridge. Finds (1-3) and situational plan (4) 
The resulting figures show that the defect part was made of the same metal. Both links were made with a similar recipe. But the amount of dopant was different. It was less for the first link. This difference didn't particularly affect the functional use. It is more important for the understanding of the process of making of horse bridle. For this case it is an additional argument in favor of manufacturing of both parts at the same time. First there was the cast of the first link, and then the second was attached to the first, which came out to be not an easy task.

The next studied element of the horse equipment - psaly - had a curved, U-shape form. According to the system of bridle straps it can be described as a pinned-perforated (Fig. 5; Fig. 6.-4). The product has a shifted from the center of the object pin (and from the center between the two extremes holes on the rod) in the form of a branch with a thorn, and also has three holes, two of which are located on the end of the main rod, and the third - at the end of branches. Psaly was cast in the two-side split mold. This is evidenced by a casting seam all over the perimeter of the product. The absence of this evidence in the apertures supports the idea of the use of special rods in this mold, i.e. holes were not drilled but were received while casting. For this purpose, a special thickening was made around the holes. In cross section, the main rod has an oval shape. The length of the curved product is $13,7 \mathrm{~cm}$, the erected size of the product increases to $16 \mathrm{~cm}$. The thickness of the rod in the center is about $0,8 \mathrm{~cm}$. The diameter of the holes is about $0,7 \mathrm{~cm}$. There are traces of the use of the product for its functional purpose. Mostly it is worn out on the rod under the fork. As for the spike, its original form has been preserved almost completely. In this point, only casting seam was worn out a little bit and a small section on the end of the projection was polished. Slight traces of wearing are visible on both sides of the branch at the point where the psaly was connected with the bit. Based on all these parameters, the product was exploited, but not very long.
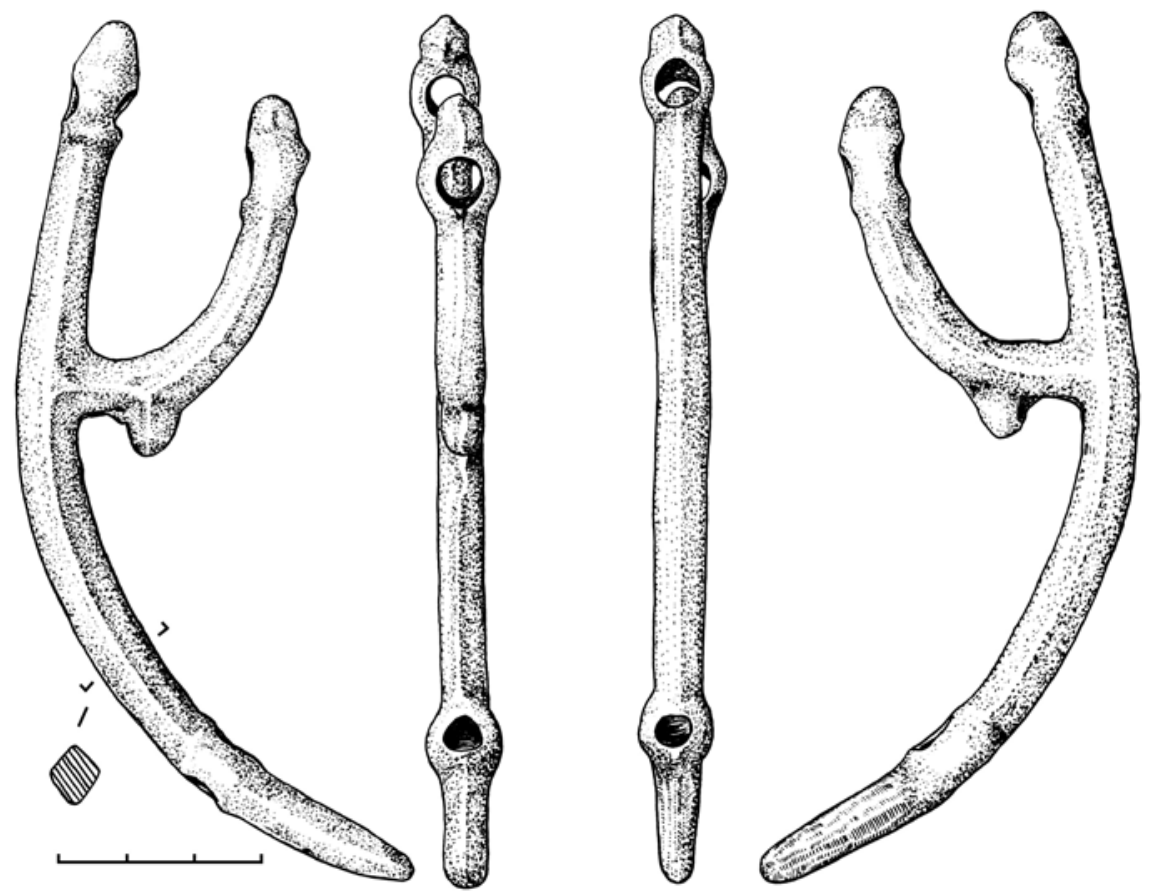

Fig. 5. Psaly from a monument Gilevsky Bridge 
In determining of the chemical composition of the alloy the surface in the center of psaly of was tested first thing: $\mathrm{Cu}-90,92 \% ; \mathrm{Sn}-6,65 \% ; \mathrm{Pb}-2,43 \%$. These figures show the increased amount of tin and lead compared to the data on the bit. This, apparently, ensures the quality of this part of the horse equipment due to the fact that psaly was subjected to a substantial load. For comparison, the surface of the product was investigated elsewhere. In particular, the pointed end was studied: $\mathrm{Cu}-88,26 \%$; $\mathrm{Sn}-8,77 \% ; \mathrm{Pb}-2,97 \%$.

Then the indicators were checked in the place where S.V. Khavrin took samples from the casting seam on the short «appendage»: $\mathrm{Cu}-87,05 \%$; $\mathrm{Sn}-7,46 \% ; \mathrm{Pb}-5,49 \%$. Just as in the previous case, without removal of oxides the long end of the fork showed the following results: $\mathrm{Cu}-84,95 \%$; $\mathrm{Sn}-9,45 \% ; \mathrm{Pb}-5,6 \%$. Finally the information about the chemical composition of the main rod, which was cleaned of patina was received: $\mathrm{Cu}-90,98 \%$; $\mathrm{Sn}-7,46 \% ; \mathrm{Pb}-1,56 \%$.

A comprehensive study of psaly consistently demonstrates a copper-tin-lead alloy. During this operation was once again a fixed tendency of intensive surface oxidation of alloying components was confirmed.

The considered bridle in combination with psaly was a unique mechanism in the form of the kinematic chain, to effectively operate the horse. On the basis of this conclusion and after the experimental modeling I stated and demonstrated the idea that the Y-shaped bronze psaly could be used in two ways: forks up or forks down [Tishkin, 1998, p. 87, Fig. 3.-5-6]. This idea was repeated 10 years later by P.I. Shul'ga [2008, p. 60, note], but without the reference to the published material of mine.

The next product (Fig. 4.-3; Fig. 6.-2) was seen in the original publication as a forehead badge [Tishkin, 1998, p. 88]. Further studies have shown that it is not the forehead badge but it can be considered as the right saddlebag clasp [Stepanova, 2006, p. 111]. This item is a circular (diameter about $3.8 \mathrm{~cm}$ ), a slightly convex bonnet to $0,3 \mathrm{~cm}$ thick with a peg in the form of T-shaped protrusion. The item was cast with a wax model in a closed mold. Casting seams are absent and on the surface of the object there are dents from fingers, joints of structural elements which are typical for the plastic material contours [Minasyan, 1994, p. 158]. A molding gate is distinctly observed on the surface of the oval pin (Fig. 6.-2). The thickness of the leg of protrusion is $0,9 \mathrm{~cm}$ in the centre, and its length $-1,3 \mathrm{~cm}$, which involves the use of multiple different belts. T-shaped clamp has an oval form with dimensions $2,2 \times 1,5 \mathrm{~cm}$, the thickness is $0,3 \mathrm{~cm}$. Similar products are available and abundant among the elements of horse equipment of the "Early Scythian" time [Kiriushin, Tishkin, 1997, Fig. 41.-4; 55.-3, 9; Stepanova, 2006, Fig. 1, 2; Shul'ga, 2008, Fig. 62.-29-44].

First the cap with X-ray fluorescence spectrometer was tested, on which there are visible traces of the emery left by the finder for visual detection of metal: $\mathrm{Cu}-83,89 \%$; $\mathrm{Sn}-13,96 \%$; As $-1,12 \% ; \mathrm{Pb}-1,03 \%$. Documented results show the difference with the previous tests on the bit and psaly. For the comparison here's the data obtained in different places of the damaged and intact surfaces:

1) $\mathrm{Cu}-83,53 \% ; \mathrm{Sn}-13,53 \% ; \mathrm{As}-1,55 \% ; \mathrm{Pb}-1,33 \% ; \mathrm{Fe}-0,06 \%$;

2) $\mathrm{Cu}-83,99 \% ; \mathrm{Sn}-13,91 \% ; \mathrm{As}-1,06 \% ; \mathrm{Pb}-1,04 \%$;

3) $\mathrm{Cu}-87,85 \%$; $\mathrm{Sn}-10,68 \% ; \mathrm{Pb}-0,57 \%$; As $-0,49 \% ; \mathrm{Fe}-0,41 \%$;

4) $\mathrm{Cu}-87,67 \%$; $\mathrm{Sn}-11,05 \%$; As $-0,61 \% ; \mathrm{Pb}-0,55 \%$; $\mathrm{Fe}-0,12 \%$.

One of the sites on the edge of the cap was mechanically released from the oxides. There were twice checked with the garget: $\mathrm{Cu}-84,14 \%$; $\mathrm{Sn}-14,22 \%$; As $-0,76 \%$; $\mathrm{Pb}-0,66 \%$; $\mathrm{Fe}-0,22 \% ; \mathrm{Cu}-86,44 \%$; $\mathrm{Sn}-12,22 \% ; \mathrm{As}-0,75 \% ; \mathrm{Pb}-0,41 \% ; \mathrm{Fe}-0,18 \%$. 


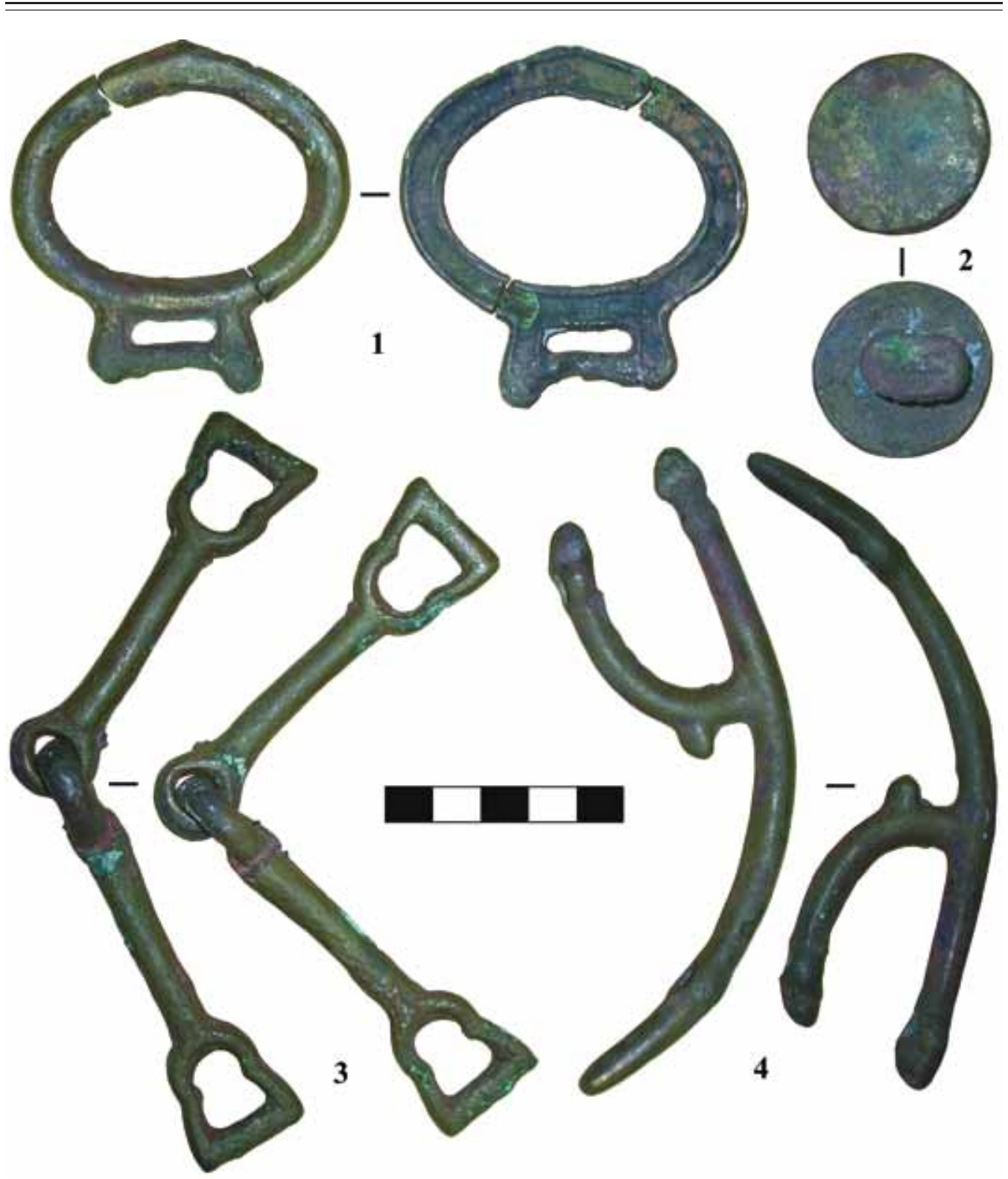

Fig. 6. Gilevsky Bridge. Bronze objects horse equipment

The "neck" of the retainer was investigated separately. First the data on the oxidized surface in the completely different places were obtained: $\mathrm{Cu}-86,2 \%$; $\mathrm{Sn}-12,56 \%$; $\mathrm{Pb}-0,73 \% ; \mathrm{Fe}-0,51 \% ; \mathrm{Cu}-85,36 \% ; \mathrm{Sn}-13,7 \% ; \mathrm{Pb}-0,62 \% ; \mathrm{Fe}-0,32 \%$. Then the area where the dark patina was mechanically removed was studied: $\mathrm{Cu}-86,13 \%$; $\mathrm{Sn}-12,6 \%$; $\mathrm{Pb}-0,77 \% ; \mathrm{Fe}-0,5 \%$.

In addition to these results, the information of the alloy composition close to the place where S.V. Khavrin samples were taken was obtained. For this the oxides from the of T-lock of the gate were removed: $\mathrm{Cu}-86,83 \% ; \mathrm{Sn}-11,86 \% ; \mathrm{As}-0,64 \% ; \mathrm{Pb}-0,49 \% ; \mathrm{Fe}-0,18 \%$. 
The resulting series of results allows us to conclude that the saddle clasp is made of bronze. Fixed heterogeneity of the alloys is typical for the ancient metal objects.

The last of the items found on the shore of the Gilevsky Bridge reservoir is the buckleblock (Fig. 4.-2; Fig. 6.-1). E.V. Stepanova [2006, p. 111, 113, Fig. 1.-1b-9b] names this element associated with a cinch saddle a loop and P.I. Shul'ga [2008, p. 32-43, 95-97, Fig. 62] names it a cinch unit. The product is cast in a closed mold with the help of a wax pattern which is obvious from the signs typical for manufacturing process of such bronze things. Traces of the gate are clearly visible on the panel next to the ledge (Fig. 4.-2). The presence of convexity and ribs, in our opinion, is an argument in favor of saving metal with the increasing of the strength of the product at the same time. The dimensions of the oval slot are as follows: $5,4 \times 4 \mathrm{~cm}$. The hole in the panel for the belt, which is fixed on this buckle-block has a length of $1,7 \mathrm{~cm}$ and a width of $0,4 \mathrm{~cm}$. The missing second buckle could have been similar to the existing, but with pin for fixing adjustable girth belt [Kiriushin, Tishkin, 1997, p. 72-74; Stepanova, 2006, Fig. 1.-1a, 9a].

The results of X-ray fluorescence analysis of the represented product are as follows:

1) the lower frame scrapped in panel: $\mathrm{Cu}-87,04 \%$; $\mathrm{Sn}-12,43 \% ; \mathrm{Pb}-0,53 \%$;

2) the front surface of the product without removing oxides: $\mathrm{Cu}-84,99 \%$; $\mathrm{Sn}-13,28 \%$; $\mathrm{Pb}-0,89 \%$; As - 0,84\%;

3) the place of breaking the tip in the framework, where S.V. Khavrin took a sample: $\mathrm{Cu}-86,87 \%$; $\mathrm{Sn}-11,74 \%$; As - 0,73\%; $\mathrm{Pb}-0,66 \%$;

4) the projection section at the gate: $\mathrm{Cu}-85,74 \% ; \mathrm{Sn}-12,41 \% ; \mathrm{Pb}-0,95 \%$; $\mathrm{As}-0,84 \%$; $\mathrm{Fe}-0,06 \%$.

All these results demonstrate by certain extent, the similarity of the manufacturing procedure with the one of the previous saddle item.

The analogy of above described elements of horse equipment are abundant [Kiriushin, Tishkin, 1997, p. 67, 69, 71-72, 74-76; Shul'ga, 2008, Fig. 52, 54, 62; et al.]. They demonstrate the features of Mayemir culture which is different from Biyken culture [Tishkin, 2011, p. 288, Fig. 12] and has its own specific characteristics, fixed in bronze casting.

\section{Conclusion}

All the results of X-ray fluorescence analysis, together with other published data [Khavrin, 2008, p. 173-178] lay the foundation for further study of metal products of Arjan-Mayemir time and for the comparative analysis with the data from the adjacent territories.

\section{References}

Abdulganeev M.T. Mayemir Mounds of Boytygem // Archaeology of the Altai Mountains. Barnaul : Publishing House of Alt. University Press, 1994. Pp. 37-43.

Borodayev V.B., Mamadakov Y.T. Burial Kyrlyk-I and-II Kyrlyk in the Altai // Mountains, Problems of Archaeological Sites in Siberia. Novosibirsk, 1985. Pp. 51-88.

Vasjutin A.S., Sadovoi A.N. On the problem of the Reconstruction of Traditional Livelihood Systems in the Early Scythian Time (Eastern Altai - burial Coo-I) // The Results of the Study of the Scythian Period of Altai and Adjacent Territories. Barnaul : Publishing House of Alt. University Press, 1999. Pp 35-38.

Volkov V.V. Bronze and Early Iron Age in Northern Mongolia. Ulaanbaatar : Shinzhleh Ukhaa Akademiiyn Hevlel, 1967. 148 p.

Volkov V.V. Deer Stones Mongolia. Moscow : Scientific World, 2002. 248 p.

Grishin Y.S. Bronze and Early Iron Age of Eastern Transbaikalia. M. : Nauka, 1975. 136 p.

Gryaznov M.P. The History of the Ancient Tribes of the Upper Ob from Excavations near the Village Big River. M. ; L. : Publishing House of the USSR Academy of Sciences, 1956. 162 p. 
Gryaznov M.P. Argens. Royal Mound of the Early Scythian time. L. : Nauka, 1980. 62 p.

Eurasia in the Scythian Epoch: Radiocarbon Chronology and Archaeological / A.Y. Alekseev, N.A. Bokovenko, V.A. Vassiliev et al. SPb. : Teza, 2005. 290 p.

Eniosova N.V., Saracheva T.G. Medieval Jewelry Craft in Europe: the Main Aspects in the History of the Study // Antiquities of Eurasia. M., 1997. Pp. 286-316.

Zavituhina M.P. Mounds and Village Bystrianskaya in the Altai Territory (Excavation of S.M. Sergeev in 1930) // Archaeological Collection of the State Hermitage. Vol. 8. L. ; M., 1966. Pp. 61-76.

Kadyrbaev M.K. Burial Zhilandy River Nura, Back Centuries. Almaty, 1974. Pp. 25-45.

Kearns T., Martinón-Torres M., Rehren T. Metal to Mould: Alloy Identification in Experimental Casting Moulds Uusing XRF // Historical Metallurgy. 2010. №44 (1). Pp. 48-58.

Kiriushin Y.F., Tishkin A.A. Scythian Epoch of the Altai Mountains. Part I: Culture of the Population in the Early Scythian Time. Barnaul : Publishing House of Alt. University Press, 1997. 232 p.

Kiriushin Y.F., Tishkin A.A., Matrenin S.S. Monument of the Scythian-Saka Time Tytkesken-VI: the Results of the Study and Cultural-Historical Analysis // "Terra Scythica". Novosibirsk, 2011. Pp. 97-116.

Kubarev V.D. Ancient Statues of Altai (Deer Stones). Novosibirsk : Nauka, 1979. 120 p.

Marsadolov L.S. Monuments of the Early Nomads in Ust-Kuyume Altai (Excavation of G.P. Sosnowsky and G.P.i Sergeyev) // Archaeological collection of the State Hermitage. Vol. 22. L., 1981. Pp. 11-22.

Marsadolov L.S. The Main Trends in the Forms Fished, Psalm and Buckles Horse in Altai in the $8^{\text {th }}-$ $5^{\text {th }} \mathrm{BC} / /$ Outfit of the Riding Horse in the Altai Region in the Early Iron Age and the Middle Ages. Barnaul : Publishing House of Alt. University Press, 1998. Pp. 5-24.

Minasyan R.S. Methods for Casting in Bronze Fished in Scythian and Scythian Burial Mounds Time // Elite Eurasian Steppes in the Scythian-Sarmatian Period. SPb., 1994. Pp. 157-163.

Minzhulin A.I. Technology Beading // SA. 1990. №4. Pp. 231-240.

Orfanou V., Rehren Th. A (not so) Dangerous Method: pXRF vs. EPMA-WDS Analyses of CopperBased Artifacts // Archaeological and Anthropological Sciences. 2014. DOI 10.1007/s12520-014-0198-Z

Savinov D.G. Deer Stones in the Culture of Eurasian Nomads. SPb. : Publishing House, St. Petersburg. University Press, 1994. 208 p.

Semenov Vl.A. Synchronization and History Monuments of Aldy-Bielsko Type in Tuva // Results of the Study of the Scythian Period of Altai and Adjacent Territories. Barnaul : Publishing House of Alt. University Press, 1999. Pp. 165-169.

Stepanova E.V. Evolution of the Horse Harness and the Relative Chronology of the Monuments of the Pazyryk Culture // Archaeological News. 2006. №13. Pp. 102-150.

Stepanova N.F. Burials in Stone Boxes and Their Dating // Burial Rites of the Ancient Tribes of Altai. Barnaul : Publishing House of Alt. University Press, 1996. Pp. 54-69.

Steppe Zone of the Asian Part of the USSR in the Scythian-Sarmatian time / M.G. Moshkova (eds.). M. : Nauka, 1992. 494 p.

Steven Shackley M. Portable X-ray Fluorescence Spectrometry (pXRF): The Good, the Bad, and the Ugly // Archaeology Southwest Magazine. 2012.Vol. 26. №2.

Stupnikov R.N. Tile Graves near the Station // Tin Chita Region, Bronze and Iron Age in Siberia. Novosibirsk : Nauka, 1974. Pp. 104-109.

Shugar A.N. Portable X-ray Fluorescence and Archaeology: Limitations of the Instrument and Suggested Methods to Achieve Desired Results // Archaeological Chemistry. 2013. VIII. Pp. 173-193.

Tishkin A.A. Burial Structures of the Bijka Burial Mound in the Altai Mountains and the Culture of the Population Who Left Them // Burial Rites of the Ancient Tribes of Altai. Barnaul : Publishing House of Alt. University Press, 1996. Pp. 20-54.

Tishkin A.A. Finds of Some Elements of Horse Equipment of the Scythian Epoch in the Foothills of Altai // Outfit of the Riding Horse in the Altai Region in the Early Iron Age and the Middle Ages. Barnaul : Publishing House of Alt. University Press, 1998. Pp. 78-90.

Tishkin A.A. Jewellery of the Early Scythian Time of the Altai Mounhtains // The Results of the Study of the Scythian Period of Altai and Adjacent Territories. Barnaul : Publishing House of Alt. University Press, 1999. Pp. 184-190.

Tishkin A.A. On the Relation of Biykenskoy and Mayemirskoy Archaeological Cultures of Altai of Early Scythian Time // Steppes of Eurasia in the Ancient and Medieval Times. Kn. 2. SPb., 2003. Pp. 164-166. 
Tishkin A.A. Creating of the Periodization Cultural and Chronological Schemes: Historical Experience So Modern Concept Study of Ancient and Medieval Peoples of Altai. Barnaul : Publishing House of Alt. University Press, 2007a. 356 p.

Tishkin A.A. Stages of Development of Biykenskaya Culture of Altai // Theory and Practice of Archaeological Research. Vol. 3. Barnaul, 2007b. Pp. 146-158.

Tishkin A.A. Biykenskaya Culture Altai-Argens Mayemirsk Time: the Content and Experience Periodization // "Terra Scythica". Novosibirsk, 2011. Pp. 272-290.

Tishkin A.A., Seregin N.N. Metal Mirror as a Source on Ancient and Medieval History of Altai (Based on the Museum of Archaeology and Ethnography of Altai State University). Barnaul : Publishing House of Alt. University Press, 2011.144 p.

Tishkin A.A., Usova I.A. "Deer" as a Source of Stone for the Reconstruction of the Costume of the Population of Asia-Argens Mayemirsk Time (Based on the Monuments of the Mongolian Altai) // Saki Saryarki Culture in the Context of the Study of Processes ethno-cultural Steppes of Eurasia. Karaganda, 2011. Pp. 158-163.

Tengeriyn ild : Hurel Zevsgiyn ye, Xiongnu Gurney Hured ed Olgiiyn Soheil, Erdenechuluun P., Erdenebaatar D. Ulaanbaatar : Narlag Mongol Onoodor, 2011. 496 p.

Khavrin S.V. Analysis of Early Scythian Bronze in Altai // Shul'ga P.I. Saddle Horse Equipment and Military Zone in Altai. Part I: Early Scythian Time. Barnaul : ABCs, 2008. Pp. 173-178.

Chlenova N.L. The Origin and Early History of the Tribes of Tagar Culture. M. : Nauka, 1967. 300 p.

Chlenova N.L. Chronology of the Monuments of Karasuk Epoch. M .: Nauka, 1972. 248 p.

Chugunov K.V. Argens-2 Reconstruction Phase of the Funeral and Memorial Complex and Some Questions of Its History // Russian Archaeological Yearbook. 2011. №1. Pp. 209-335.

Shul' ga P.I. Saddle Horse Equipment and Military Zone in Altai. Part I: Early Scythian time. Barnaul : ABCs, 2008. 276 p.

Čugunov K.V., Parzinger H., Nagler A. Der skythenzeitliche Fürstenkurgan Aržan 2 in Tuva. Mainz : Verlag Philipp von Zabern, 2010. 330 S. +153 Taf.

\section{А.А. Тишкин \\ МЕТАЛЛИЧЕСКИЕ ИЗДЕЛИЯ АРЖАНО-МАЙЭМИРСКОГО ВРЕМЕНИ С АЛТАЯ: РЕНТГЕНОФЛЮОРЕСЦЕНТНЫЙ АНАЛИЗ И КУЛЬТУРНО-ХРОНОЛОГИЧЕСКАЯ АТРИБУЦИЯ}

В настоящее время перед российскими археологами стоит задача более интенсивного изучения уже накопленных материалов. Для этого используются современные естественно-научные методы, направленные на получение необходимого объема объективной информации для проверки ранее сформулированных выводов, концепций и предположений, а также для выхода на новый уровень исследовательской деятельности. В этом процессе важное значение имеют определения химического состава металлических изделий. Особую ценность такие данные приобретают там, где работа вообще не проводилась либо реализовывалась фрагментарно. Автором статьи намечена и последовательно выполняется программа изучения предметов аржано-майэмирского времени (конец IX - 2-3-я четверти VI в. до н.э.) с помощью рентгенофлюоресцентного спектрометра ALPHA SERIES ${ }^{\mathrm{TM}}$ (Альфа-2000, производство США), который имеется на кафедре археологии, этнографии и музеологии Алтайского государственного университета. Публикуемые результаты базируются на проведенных исследованиях, в основу которых легли археологические находки, хранящиеся в Музее археологии и этнографии Алтая Алтайского государственного университета (г. Барнаул). Наиболее представительной является коллекция, полученная при раскопках памятника Элекмонар-II. Кроме этого, привлекались древние предметы из таких археологических комплексов, как Бийке, Бойтыгем-II и Тыткескень-VI. Все они демонстрируют различные этапы развития бийкенской археологической культуры. В качестве сравнительного материала из музея привлечен неполный комплект элементов конского снаряжения, который отражает другую традицию в рамках обозначенного хронологического периода. Изделия из местонахождения Гилевский мост относятся к майэмирской (майемерской) культуре.

Ключевые слова: Алтай, аржано-майэмирское время, рентгенофлюоресцентный анализ, спектрометр, музей, орудия труда, предметы вооружения, украшения, детали одежды, конское снаряжение. 